\title{
PENINGKATAN KESADARAN PENGGUNAAN ALAT KESELAMATAN PELAYARAN BAGI NELAYAN DI KABUPATEN MUSI BANYUASIN
}

\author{
Driaskoro Budi Sidharta ", Sri Kelana, Slamet Prasetyo Sutrisno \\ Program Studi Teknologi Nautika \\ Politeknik Transportasi Sungai Danau dan Penyeberangan Palembang \\ Jl. Sabar Jaya No. 116 Desa Perajin Banyuasin - Sumatera Selatan \\ Email Korspondensi: *budi.driaskoro@gmail.com
}

Received : October 30, 2020 ; Accepted : November 13, 2020 ; Published : January $1^{\text {st }}, 2021$

\begin{abstract}
Abstrak
Salah satu peran penting dalam penggunaan alat keselamatan pelayaran adalah sebagai bentuk upaya untuk mencegah atau meminimalisir resiko kecelakan bagi nelayan. Kesadaran yang rendah dan didukung dengan harga peralatan keselamatan yang dirasa cukup mahal membuat nelayan di Kabupaten Musi Banyuasin kurang peduli terhadap pentingnya alat keselamatan pelayaran. Kegiatan pengabdian ini bertujuan untuk memberikan pengetahuan tentang keselamatan berlayar bagi para nelayan di kabupaten Musi Banyuasin. Pemberian pengetahuan serta bantuan peralatan keselamatan bagi para peserta penyuluhan ini bermaksud agar terjadi peningkatan kemampuan, sikap dan kesadaran para nelayan di Kabupaten Musi Banyuasin tentang pentingnya keselamatan serta mengenal teknik penyelamatan diri saat terjadi kecelakaan pada saat berlayar. Kegiatan ini dilaksanakan dengan metode pelatihan dengan ceramah dan diskusi antara narasumber dan peserta dengan materi fokus pada keselamatan pelayaran. Hasil kegiatan ini, menunjukkan adanya peningkatan kesadaran peserta akan pentingnya keselamatan pelayaran dan pemahaman teknik penyelamatan diri saat terjadi kecelakaan. Bantuan lifejacket yang diberikan mampu membantu para peserta melengkapi peralatan keselamatan pelayaran pada saat bekerja mencari ikan.
\end{abstract}

Kata Kunci: alat keselamatan pelayaran, nelayan, teknik penyelamatan diri

\begin{abstract}
One of the important roles in using shipping safety equipment is an effort to prevent or minimize accidents for fishermen. The low awareness and the price of safety equipment that is considered quite expensive make fishermen in Musi Banyuasin regency less caring about the importance of shipping safety equipment. The program was carried out to share knowledge about safety voyage for fisherman Musi Banyuasin regency. It was held to improve skill, attitude, and awareness of fisherman in Musi Banyuasin regency regarding to the importance of safety, life saving technique in accident case. This program was conducted by lectures and discussion method between speaker and participants focusing in safety voyage. The results showed that the participant's awareness of safety voyage importance and understanding of life saving technique have increased. The lifejackets were given to help participants to comply the life saving requirement during fishing.
\end{abstract}

Keywords : shipping safety equipmen, fisherman, life saving technique 


\section{Pendahuluan}

Kabupaten Musi Banyuasin (Muba) merupakan salah satu kabupaten di Provinsi Sumatera Selatan yang memiliki potensi alam yang besar seperti perkebunan sawit dan sumber daya alam gas bumi. Potensi sumber daya alam gas baru berupa cadangan gas di Blok Sakamembang dan telah dilakukan uji produksi oleh Repsol[1]. Potensi alam lainnya berupa aliran sungai besar diantaranya Sungai Musi dan Sungai Batang Hari Leko. Masyarakat Musi Banyuasin memanfaatkan sungai yang dalam dan lebar sebagai prasarana transportasi alternatif yang menghubungkan satu wilayah dengan wilayah yang lain[2]. Terdapat 620 jenis ikan yang hidup di Sungai Musi dan Pesisir Timur Sumatera Selatan[3] bahkan ikan elang (tiger fish) menjadi salah satu ikan buruan masyarakat di sepanjang Sungai Lalan Kabupaten Musi Banyuasin[4].

Nelayan di sepanjang sungai di daerah Musi Banyuasin memanfaatkan kapal ukuran kecil yang sering disebut dengan perahu ketek untuk mencari dan menangkap ikan. Akan tetapi para nelayan tersebut kurang memperhatikan keselamatan selama berlayar tanpa menggunakan alat-alat pengaman. Kecelakaan kapal di sungai masih sering terjadi di sepanjang sungai Musi karena masih kurangnya kelengkapan alat pengaman yang tersedia diatas kapal. Sementara keberadaan dan penggunaan perlengkapan keselamatan kerja yang sesuai dengan standar dapat memperkecil risiko dan menghindarkan dari akibat yang fata[5][6] mengatakan bahwa prosentase penyebab terjadinya musibah kecelakaan kapal di Indonesia disebabkan beberapa faktor, yaitu: 43,67\% disebabkan kesalahan manusia (human error), $32,37 \%$ disebabkan oleh alam dan $23,94 \%$ oleh faktor teknis. Pengetahuan dan keterampilan tentang keselamatan kerja dari awak kapal dapat memperkecil resiko kecelakaan[7].

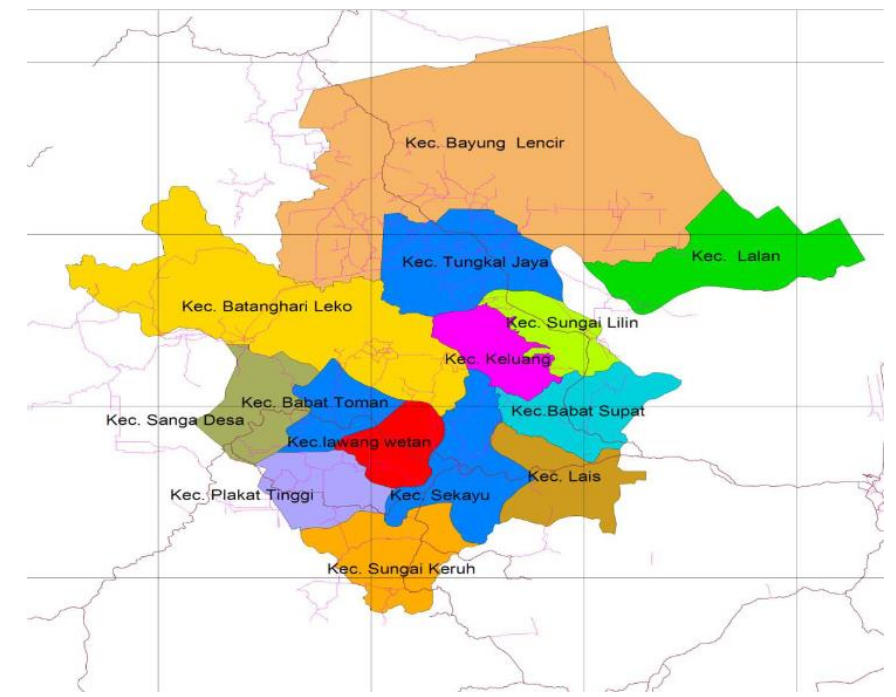

Gambar 1. Peta Kabupaten Musi Banyuasin

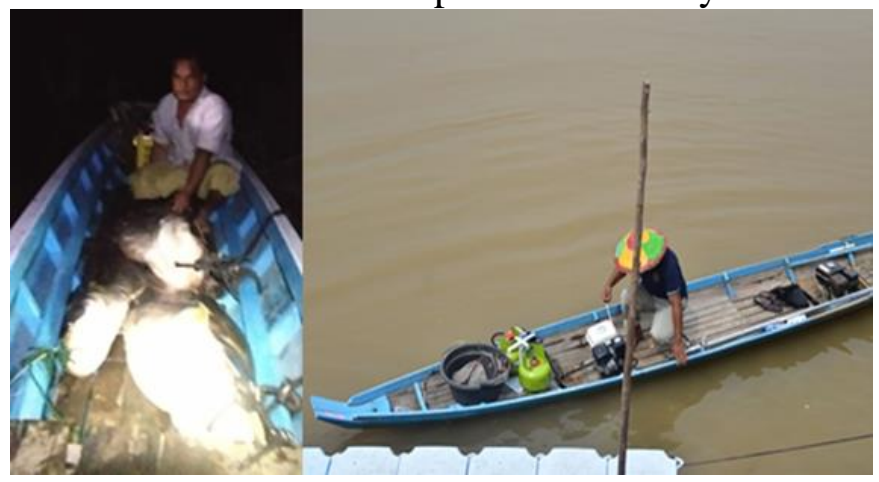

Gambar 2. Potret nelayan Kabupaten Muba tanpa menggunakan alat keselamatan 
Peningkatan pengetahuan tentang keselamatan berlayar bagi nelayan diharapkan mampu meminimalisir terjadinya kecelakaan serta akan mampu memberikan keselamatan bagi nelayan itu sendiri. Peningkatan pengetahuan tersebut dapat diwujudkan melalui kegiatan penyuluhan keselamatan pelayaran. Adapun tujuan program ini untuk memberikan pengetahuan tentang keselamatan berlayar bagi para nelayan di kabupaten Musi Banyuasin dengan harapan terjadi peningkatan kemampuan, sikap dan kesadaran para nelayan tentang pentingnya keselamatan. Untuk melakukan perubahan dari kebiasaan tidak menggunakan alat keselamatan disaat berlayar membutuhkan proses yang lama karena perlu pendekatan secara sosial, agama dan kebudayaan yang berkembang di wilayah[6].

\section{Metode}

Kegiatan penyuluhan keselamatan ini merupakan wujud pengabdian kepada masyarakat yang dilakukan oleh pihak Politeknik Transportasi Sungai Danau dan Penyeberangan Palembang bagi masyarakat nelayan di Kabupaten Musi Banyuasin. Untuk menunjang tercapainya tujuan penyuluhan yang efektif dan efisien, maka penyampaian materi dilakukan dengan metode pelatihan dengan ceramah dan diskusi sehingga peserta memperoleh kesempatan untuk menyampaikan pendapat ataupun pertanyaan. Kerelevansian suatu metode dengan tujuan dalam kegiatan belajar mengajar mempunyai andil dalam menentukan kemampuan yang diharapkan dari anak didik[8]. Strategi pembelajaran dapat dilakukan dengan ceramah, kegiatan percobaan (praktikum), studi banding, diskusi maupun bertanya jawab[9]. Kegiatan pengabdian kepada masyarakat ini mengikuti model pendekatan kualitatif dan kuantitatif. Manajemen kegiatan meliputi Identifying, Planning, Organizing, Acting, Impact yang tergambar pada alur berikut[10] :

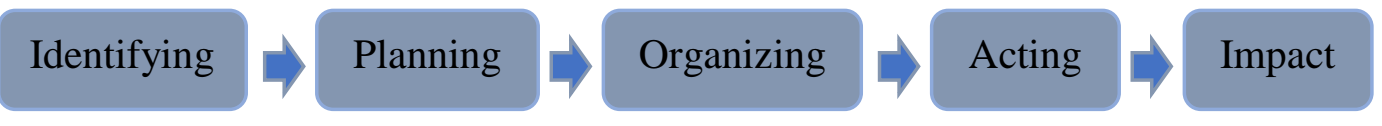

Gambar 3. Alur kegiatan pengabdian kepada masyarakat

1. Kegiatan identifikasi dilakukan dengan cara bekerjasama dengan pihak Dinas Perikanan Kabupaten Banyuasin sebagai pembina para nelayan dan Dinas Perhubungan sebagai salah satu stakeholder Politeknik Transportasi Sungai Danau dan Penyeberangan Palembang di bidang transportasi. Identifikasi dilakukan dalam rangka memperoleh peserta penyuluhan yang tepat sasaran baik dari aspek ilmu maupun materi (peralatan) keselamatan yang akan disumbangsihkan bagi masyarakat. Pihak Dinas Perikanan Kabupaten Muba melakukan pemilihan terhadap 100 orang calon peserta yang merupakan nelayan binaan yang terdaftar dalam database Dinas Kabupaten Muba.

2. Tahapan perencanaan dan pengorganisasian dilakukan agar kegiatan berjalan dengan tepat sasaran, efektif, efisien, dan bermanfaat sesuai dengan tujuan yang telah ditetapkan. Perencanaan dan pengorganisasian terkait dengan jadwal, penentuan temphapan ini dilakukan secara internal di lingkungan Politeknik Transportasi Sungai Danau dan Penyeberangan Palembang dan eksternal dengan pihak Dinas Perikanan dan Perhubungan Kabupaten Muba.

3. Tahapan berkutnya merupakan tahap implementasi dan aksi di lapangan berupa penyuluhan keselamatan bagi para nelayan.

4. Impact atau dampak dari kegiatan dievaluasi selama dan sesudah pelaksanaan kegiatan. Gambaran dampak dari kegiatan bersiafat deskriptif kualitatif berupa hal yang dapat dilihat dan dirasakan oleh semua pihak yang terlibat dalam kegiatan.

Beberapa hal yang terkait dengan pelaksanaan penyuluhan keselamatan bagi nelayan di Kabupaten Muba tersebut, adalah :

a) Peserta 
Peserta penyuluhan keselamatan tersebut terdiri atas 100 orang yang merupakan para nelayan dari kecamatan Lawang Wetan, Sanga Desa, Sekayu, Babat Toman.

b) Rangkaian kegiatan pelaksanaan

1) Penyuluhan tersebut dilakukan melalui kerjasama dengan Pihak Dinas Perikanan dan Dinas Perhubungan Kabupaten Musi Banyuasin. Dinas Perikanan Kabupaten Banyuasin dalam hal ini merupakan instansi Pembina bagi para nelayan tersebut. Kegiatan tersebut dilaksanan selama 1 hari pada tanggal 15 Oktober 2020 di Dermaga Dinas Perhubungan Kabupaten Musi Banyuasin. Pihak Dinas Perikanan Kabupaten Musi Banyuasin melakukan pendataan dan pemanggilan terhadap 100 orang nelayan yang berada di 4 (empat) kecamatan tersebut.

2) Dikarenakan kegiatan penyuluhan ini dilaksanakan pada masa pandemic corona, maka pihak Dinas Perikanan Kabupaten Muba bekerjasama dengan pihak Dinas Kesehatan Kabupaten Muba dalam mempersiapkan peralatan cuci tangan. Kegiatan ini juga diawali dengan rapid test bagi seluruh peserta.

3) Registrasi ulang peserta dilakukan oleh panitia sekaligus pembagian kaos seragam dan tanda peserta bagi peserta.

4) Penyampaian materi keselamatan pelayaran dilakukan oleh dosen Polteknik Transportasi Sungai Danau dan Penyeberangan Palembang yang dilanjutkan dengan acara makan siang bersama dengan para peserta.

5) Kegiatan tersebut melibatkan beberapa taruna Politeknik Transportasi Sungai Danau dan Penyeberangan dengan beberapa kegiatan tambahan berupa :

a. Pembagian life jacket bagi seluruh peserta.

b. Pembagian Alat tulis beserta baju seragam yang digunakan selama kegiatan penyuluhan.

c. Pembagian uang saku bagi seluruh peserta

c) Peralatan

Untuk menunjang kegiatan penyuluhan tersebut, digunakan peralatan pendukung antara lain :
a. Laptop
b. LCD Proyektor
c. Slide Materi
d. Sound System
e. Life jacket

\section{Hasil dan Pembahasan}

Penyuluhan mengandung maksud dan tujuan tertentu sehingga informasi yang disampaikan harus mudah dimengerti, dipahami dan diterapkan oleh semua pihak yang terlibat[11]. Kegiatan penyuluhan keselamatan pelayaran bagi nelayan tersebut secara umum bertujuan untuk memberikan pengetahuan dan pemahaman pentingnya peralatan keselamatan diatas kapal ataupun perahu. Teknik penyelamatan diri dalam keadaan darurat merupakan salah satu materi yang disampaikan dalam penyuluhan ini diantaranya pemanfaatan jerigen minyak bekas sebagai pelampung alternatif. Edukasi tentang pemanfaatan jerigen sebagai peralatan alternatif saat keaadan darurat disampaikan pada peserta penyuluhan seperti yang telah dilakukan oleh Basarnas Jakarta dalam latihan SAR menghadapi kecelakaan kapal[12].

Adapun materi penyuluhan terdiri dari materi pokok bahasan yaitu :

1) Pentingnya peralatan keselamatan

2) Penyelamatan diri dalam keadaan darurat

3) Peralatan keselamatan pengganti (alternatif) dalam keadaan darurat

Setelah penyampaian materi dilanjutkan dengan sesi tanya jawab antara narasumber dan seluruh peserta. Metode tanya jawab berguna untuk mengarahkan pengamatan peserta 
didik pada bagian penting dari materi yang disampaikan sehingga hal-hal yang belum dimengerti tampak ke permukaan[13]. Metode tanya jawab mampu menjadi metode pembelajaran yang efektif meningkatkan capaian belajar[14]. Pertanyaan pada sesi diskusi didominasi oleh pertanyaan terkait peralatan keselamatan pengganti dan cara penggunaannya. Berdasarkan penjelasan dari para peserta bahwa yang menjadi kendala terbesar bagi peserta dalam penyediaan alat keselamatan pelayaran tersebut adalah biaya pengadan atau pembelian alat keselamatan tersebut. Berdasarkan hal tersebut, maka pihak narasumber mengenalkan beberapa peralatan keselamatan pengganti diantaranya jerigen, botol mineral berbahan plastik. Narasumber menjelaskan bagaimana teknik pembuatan alat keselamatan alternatif tersebut dan termasuk cara penggunaannya, teknik evakuasi serata cara meminta bantuan pertolongan bila terjadi kecelakaan. Berikut merupakan gamabaran jalannya kegiatan penyuluhan.
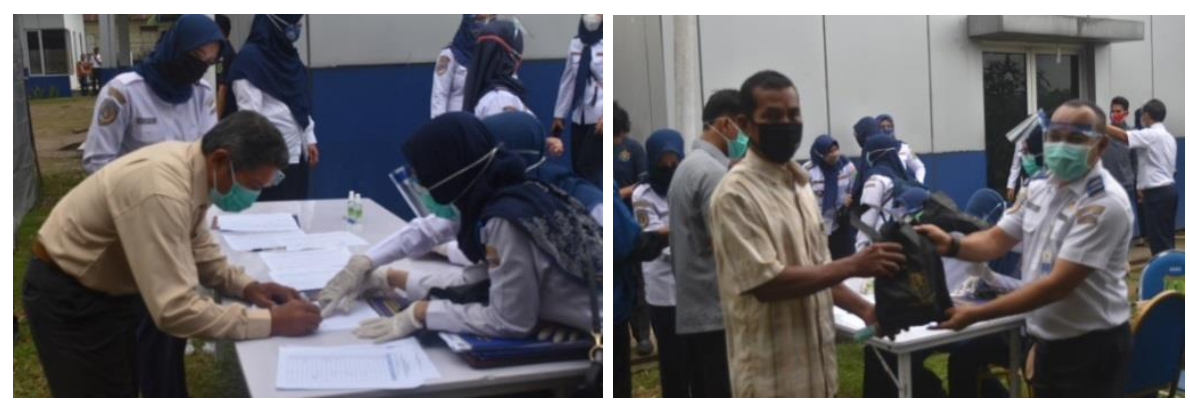

Gambar 4. Proses registrasi ulang dan pembagian seragam peserta
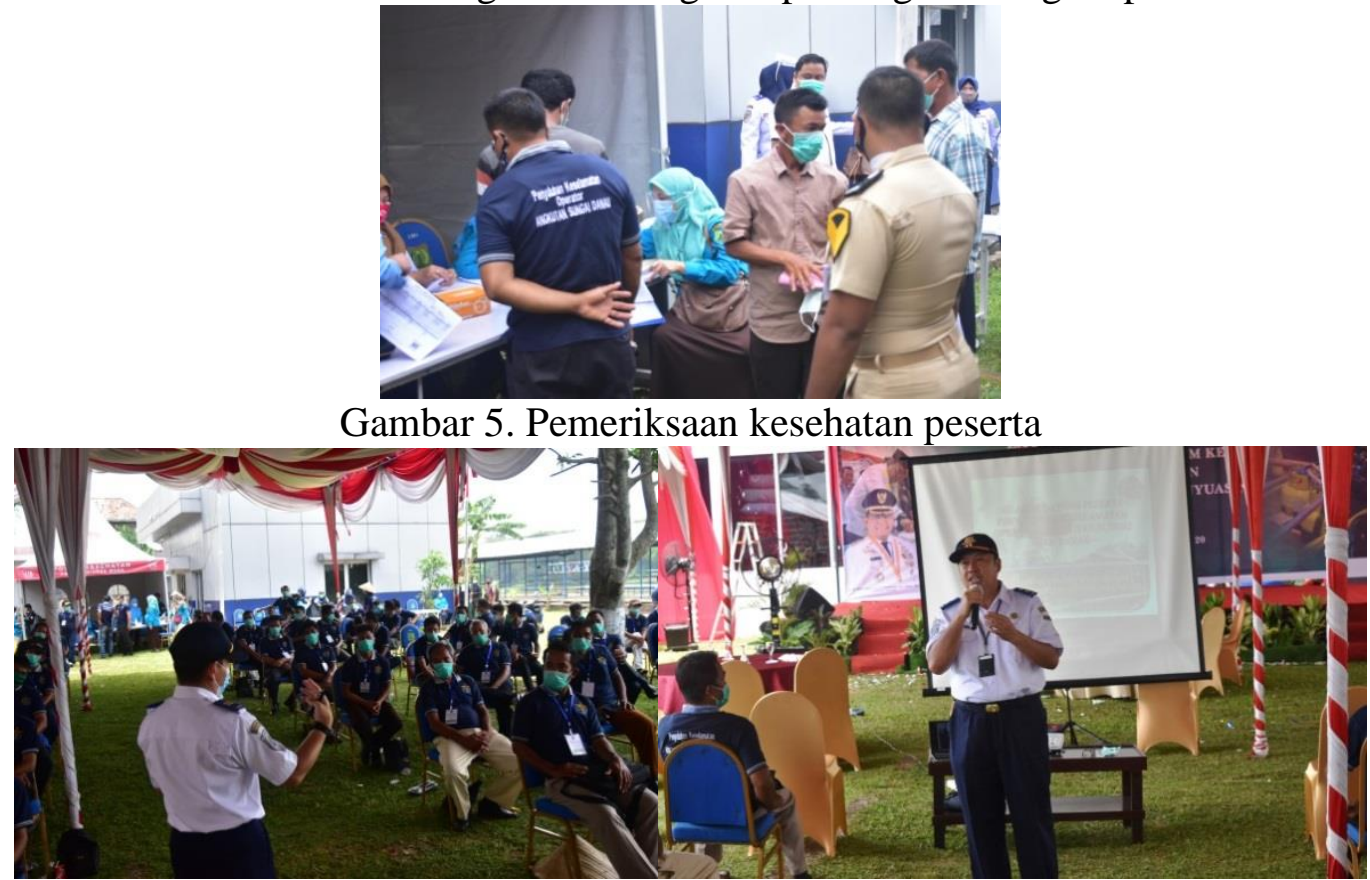

Gambar 6. Kegiatan penyampaian materi 


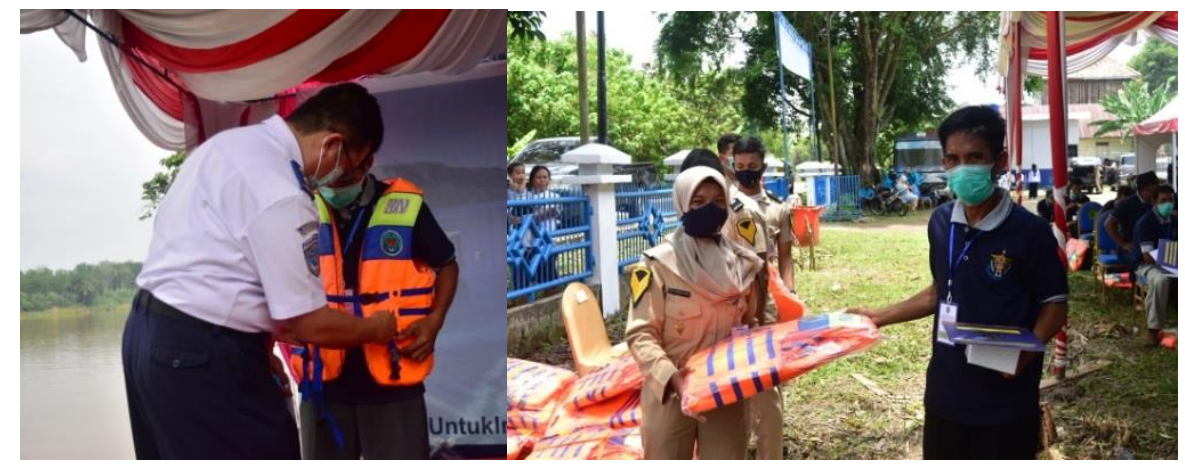

Gambar 7. Penyerahan bantuan lifejacket bagi peserta

Dari serangkaian kegiatan penyuluhan yang telah dilaksanakan terlihat adanya respon yang cukup baik dari peserta maupun pihak perintah daerah yaitu Dinas Perikanan dan Dinas Perhubungan Kabupaten Muba. Antusisme peserta selama kegiatan berlangsung sangat tinggi terlihat dari keseriusan dan kesungguhan peserta dalam mengikuti dan menanggapi materi yang disampaikan oleh narasumber.

Evaluasi dilakukan terhadap kegiatan tersebut untuk mengetahui tingkat capaian dari tujuan kegiatan yang telah dirancang. Hasil evaluasi merupakan informasi yang menunjukkan apakah tujuan pelatihan telah tercapai [15]. Hasil evaluasi disajikan dalam tabel 1.

Tabel 1. Hasil evaluasi kegiatan

\begin{tabular}{|c|c|c|}
\hline Masalah & Solusi & \\
\hline $\begin{array}{l}\text { [1]Peserta } \\
\text { memilil } \\
\text { karena }\end{array}$ & $\begin{array}{l}\text { Memberikan bantuan life } \\
\text { jacket kepada peserta } \\
\text { penyuluhan }\end{array}$ & $\begin{array}{l}\text { Seluruh peserta }(100 \%) \\
\text { memiliki } 1 \text { buah } \\
\text { pelampung sebagai bekal } \\
\text { alat keselamatan saat } \\
\text { mencari ikan }\end{array}$ \\
\hline $\begin{array}{l}\text { [2] Peserta belum } \\
\text { memiliki pengetahuan } \\
\text { tentang alat } \\
\text { keselamatan } \\
\text { alternative. }\end{array}$ & $\begin{array}{ll}\text { Memberikan } & \text { pengetahuan } \\
\text { tentang } & \text { bahan-bahan } \\
\text { alternatif yang dapat } \\
\text { digunakan sebagai alat } \\
\text { keselamatan dalam keadaan } \\
\text { darurat }\end{array}$ & $\begin{array}{l}\text { Seluruh peserta (100\%) } \\
\text { memahami bahan-bahan } \\
\text { yang dapat digunakan } \\
\text { sebagai alat keselamatan } \\
\text { saat keadaan darurat }\end{array}$ \\
\hline $\begin{array}{l}\text { [3] Peserta } \\
\text { memah } \\
\text { penyel } \\
\text { saat ke }\end{array}$ & $\begin{array}{l}\text { erikan pemahaman } \\
\text { peserta tentang tek } \\
\text { nyelamatan diri saat } \\
\text { n darurat }\end{array}$ & $\begin{array}{l}\text { Seluruh peserta }(100 \%) \\
\text { mengetahui cara } \\
\text { menyelamatkan diri pada } \\
\text { keadaan darurat }\end{array}$ \\
\hline
\end{tabular}

Kegiatan penyuluhan ini telah mampu membantu menumbuhkan pemahaman dan kesadaran peserta tentang penting keselamatan dan pentingnya keberadaan alat-alat keselamatan diatas perahu. Dalam sesi diskusi tercermin bahwa peserta telah menyadari akan pentingnya peralatan keselamatan namun sebagian besar peserta belum memiliki kemampuan untuk menyediakan peralatan keselamatan. Berdasarkan respon atas pertanyaan yang disampaikan oleh narasumber kepada seluruh peserta menggambarkan bahwa seluruh peserta $(100 \%)$ paham atas materi yang telah disampaikan. Seluruh peserta menyatakan paham atas semua penjelasan narasumber. Kegiatan penyuluhan tersebut memperoleh tanggapan positif dari pihak pemerintah setempat dikarenakan setelah penyuluhan ini pemerintah setempat berharap tingkat kecelakaan nelayan di Kabupaten Muba dapat dikurangi. 


\section{Kesimpulan}

Tingkat kesadaran dan pemahaman masyarakat nelayan akan semakin meningkat melalui kegiatan penyuluhan keselamatan pelayaran tersebut. Luaran dari kegiatan ini adalah meningkatnya kesadaran masyarakat nelayan yang tinggal di wilayah Kabupaten Muba terhadap pentingnya keselamatan dalam pelayaran. Hal tersebut dapat terlihat dari pemahaman peserta tentang teknik penyelamatan diri dan cara penggunaan bahan alternative sebagai alat keselamatan pada keadaan darurat. Dengan capaian tersebut, diharapkan dalam berlayar untuk menangkap ikan, para nelayan telah memperhatikan aspek-aspek keselamatan.

\section{Daftar Pustaka}

[1] D Wulandari. (2019) Musi Banyuasin Masih Potensial sumber Migas Nasional. [Online]. HYPERLINK "https://sumatra.bisnis.com/read/20190222/534/892239/musibanyuasin-masih-potensial-sumber-migas-nasional" https://sumatra.bisnis.com/read/20190222/534/892239/musi-banyuasin-masihpotensial-sumber-migas-nasional

[2] F S Puriningsih and Syafril Syafril, "Penelitian Pengembangan Titik Simpul Potensial Transportasi Sungai Di Kabupaten Musi Banyuasin," Jurnal Penelitian Transportasi Laut, 2018.

[3] Taufik Wijaya. (2018, Desember) Berapa Jenis Ikan yang Hidup di Sungai Musi dan Pesisir Timur Sumatera Selatan? [Online]. HYPERLINK "https://www.mongabay.co.id/2018/12/08/berapa-jenis-ikan-yang-hidup-di-sungaimusi-dan-pesisir-timur-sumatera-selatan/" https://www.mongabay.co.id/2018/12/08/berapa-jenis-ikan-yang-hidup-di-sungai-musidan-pesisir-timur-sumatera-selatan/

[4] Edy Parmansyah. (2020, Juli) Tidak Disangka, Diam-diam Bayung Lencir Simpan Potensi Ikan Hias Impor. [Online]. HYPERLINK "https://www.detiksumsel.com/tidakdisangka-diam-diam-bayung-lencir-simpan-potensi-ikan-hias-impor/" https://www.detiksumsel.com/tidak-disangka-diam-diam-bayung-lencir-simpanpotensi-ikan-hias-impor/

[5] A G Santara, F Purwangka, and B H Iskandar, "Peralatan Keselamatan Kerja Pada Perahu Slerek di PPN Pengambengan, Kabupaten Jembrana, Bali," Jurnal IPTEKS PSP, Vol. 1 (1), 2014.

[6] H Lumaksono, H Soeroso, and B Teguh, "Penerapan Penggunaan Alat Keselamatan Pada Saat Berlayar Untuk Kelompok Nelayan Madura," in Seminar Nasional Hasil Pengabdian Masyarakat, Madura, 2017.

[7] F Purwangka, Riris Nurkayah, and Mohammad Imron, "Pengetahuan dan Keterampilan Nelayan Tentang Keselamatan Kerja Di PPP Muncar, Banyuwangi," ALBACORE, pp. 99-109, 2017.

[8] Samsul Ependi, "Penerapan Metode Tanya Jawab Untuk Meningkatkan Prestasi Belajar Bahasa Indonesia siswa Kelas VI SD Negeri 012 Pangkalan Baru Kecamatan Siak Hulu," Primary : Jurnal Pendidikan Guru Sekolah Dasar Fakultas Keguruan dan Ilmu Pendidikan Universitas Riau Vol 7 (2), pp. 256-264, 2018.

[9] Gunarti Sukriyatun, "Penerapan Metode Tanya Jawab untuk Meningkatkan Pemahaman Peserta Didik Pada Mata Pelajaran IPS (Sejarah) Di Kelas 9.1 Tentang Perang Dunia II, Di SMPN 16 Kota Bogor Tahun Pelajaran 2012 / 2013," Istoria Vol 12, No 1 (2016), 2016.

[10] Marianus Mantovanny Tapung, Max Regus, and Ruben Marsel Payong, "Bantuan Sosial Dan Pendidikan Kesehatan Bagi Masyarakat Pesisir yang Terdampak SosialEkonomi Selama Patogenesis Covid-19 di Manggarai," Transformasi: Jurnal Pengabdian Masyarakat 16 (1), pp. 12-26, 2020. 
[11] Suko Pratomo, "Pengaruh Strategi Penyuluhan dan Tingkat Pendidikan Terhadap Kepedulian Kesehatan Lingkungan," Metodik Didaktik Vol.9 (2), 2015.

[12] Basarnas. (2019, Oktober) Basarnas Jakarta Gelar Latihan SAR Daerah Terhadap Kecelakaan Kapal di Wilayah Teluk Jakarta dan Kepulauan Seribu. [Online]. HYPERLINK "https://basarnas.go.id/artikel/basarnas-jakarta-gelar-latihan-sar-daerahterhadap-kecelakaan-kapal-di-wilayah-teluk-jakarta-dan-kepulauan-seribu" https://basarnas.go.id/artikel/basarnas-jakarta-gelar-latihan-sar-daerah-terhadapkecelakaan-kapal-di-wilayah-teluk-jakarta-dan-kepulauan-seribu

[13] Dyah Wuryaning Luhrini , "Metode Tanya Jawab Multiarah Sebagai Upaya Untuk Meningkatkan Prestasi Belajar Matematika Siswa Kelas III Semester Ii Tahun Pelajaran 2016/2017 SD Negeri 4 Tonja," ADI WIDYA: Jurnal Pendidikan Dasar Vol 3 (1), 2018.

[14] Fathony, "Pengaruh Metode Tanya Jawab Terhadap Hasil Belajarsiswa di SMK Negeri 1 Peranap Kabupaten Indragiri Hulu," Jurnal Pendidikan Tambusai vol. 3 (1), 2019.

[15] Evie Sopacua and Didik Budijanto, "Evaluasi 4 Tahap dari Kirkpatrick Sebagai Alat Dalam Evaluasi Pasca Pelatihan," Buletin Penelitian Sistem Kesehatan Vol.10 (4), pp. 371-379, 2007. 